\title{
Öğretmen Adaylarının Sosyal Aktivite Tercihlerinin İkili Karşılaştırmalı Ölçekleme Yöntemiyle Belirlenmesi
}

\author{
Determination of Candidate Teachers' Social Activity \\ Preferences by Pair-Wise Comparision Scaling Method
}

\author{
Betül POLAT * $\quad$ H. Çağlar GÖKSEL **
}

\begin{abstract}
Özet
$\mathrm{Bu}$ araştırmada öğretmen adaylarının tercih ettikleri sosyal aktivitelerin öğretmen adaylarının görüşleri doğrultusunda ikili karşılaştırmalı ölçekleme yöntemiyle belirlenmesi ve elde edilen ölçek değerlerinin öğretmen adaylarının öğrenim gördüğü üniversiteye, üniversiteye giriş puan türüne ve cinsiyetlerine göre karşılaştırılması amaçlanmıştır. Bu amaç doğrultusunda hazırlanan Sosyal Aktivite Tercih Ölçeği, 2012-2013 eğitim öğretim yılında, Niğde Üniversitesi Eğitim Fakültesi Fen Bilgisi, Sınıf Öğretmenliği, Türkçe, Sosyal Bilgiler, Resim ve Müzik Eğitimi ve Rehberlik ve Psikolojik Danışmanlık bölümlerinde öğrenim gören 174 ile Bülent Ecevit Üniversitesi Ereğli Eğitim Fakültesi Sınıf Öğretmenliği, Fen Bilgisi, İlköğretim Matematik ve Türkçe Eğitimi bölümlerinde öğrenim gören 201 olmak üzere toplam 375 gönüllü öğretmen adayına uygulanmıştır. Yapılan ölçekleme sonucunda, her iki üniversitedeki öğretmen adaylarının sosyal aktivite tercihleri arasında uyum olduğu belirlenmiştir. Puan türüne göre sosyal aktivite tercihleri karşılaştırıldığında sayısal, eşit ağırlık ve sözel puan türüne göre üniversiteye giren öğretmen adaylarının tercihleri arasında uyum olduğu fakat yetenek puan türüne göre üniversiteye girenlerin sosyal aktivite tercihlerinde diğer puan türlerine göre farklılıklar olduğu belirlenmiştir. Öğretmen adaylarının sosyal aktivite tercihleri cinsiyetlerine göre karşılaştıııldığında ise kadın ve erkek öğretmen adaylarının en az ve en çok tercih ettikleri aktivitelerin aynı olduğu fakat diğer aktivite tercihleri arasında farklılıklar olduğu belirlenmiştir.
\end{abstract}

Anahtar kelimeler: Öğretmen adayı, sosyal aktivite, ölçekleme, ikili karşılaştırmalar yöntemi

\begin{abstract}
The aim of this study is to determine the candidate teachers' preferences of social activities in accordance with their opinions with the scaling method of pair wise comparison and compare the results according to the universities they graduate, their type of scores in University Entrance Exam and their genders. In the 20122013 educational year, the Social Activity Preference Scale, prepared in accordance with this aim, has been conducted to 174 voluntary candidate teachers from the Science Teaching, Primary School Teaching, Turkish Teaching, Social Sciences Teaching, Art Teaching, Music Teaching and Psychological Counseling and Guidance departments of Niğde University Faculty of Education and 201 voluntary candidate teachers from the Science Teaching, Elementary Mathematics Teaching and Turkish Teaching departments of Bülent Ecevit University. As a result of the scaling, it has been determined that there is a consistency between the preferences of the candidate teachers from the two universities. When compared according to the types of University Entrance Exam scores, the preferences of the candidate teachers with the scores of numeric, verbal and equally weighted exams are consistent, while the candidate teachers who are accepted to university according to the scores of talent exam have different preferences of social activities. When compared according to the genders, the preferences of the candidate teachers it has been determined that the most and least preferred social activities of the two genders are the same but the preferences of the other activities are changeable.
\end{abstract}

Key Words: candidate teacher, social activity, scaling, pair wise comparison method

\footnotetext{
* Arş. Gör., Niğde Üniversitesi, Eğitim Fakültesi, Eğitim bilimleri Bölümü, Eğitimde Ölçme ve Değerlendirme Anabilim Dalı, e-posta: bpolat@nigde.edu.tr

** Arş. Gör., Bülent Ecevit Üniversitesi, Ereğli Eğitim Fakültesi, e-posta: caglar.goksel@ gmail.com
} 


\section{GIRIS}

İnsan biyolojik bir varlık olduğu kadar sosyal bir varlıktır. Bu nedenle insanların kendilerini gerçekleştirebilmeleri için dünyaya geldiklerinden itibaren fizyolojik gereksinimlerinin yanında sosyalleşme gereksinimlerini de karşılamaları gerekir. Çünkü sosyalleşme, bir gruba ait olmak, insanın temel ihtiyaçları arasındadır. Sosyalleşme yaşam boyu süren bir öğrenme sürecidir. İnsan, doğumundan ölümüne kadar sürekli bir sosyalleşme içerisindedir (Kağıtçıbaş1, 2010). Binbaşığlu'na (1982) göre sosyalleşme, kişinin yetişkin çevresinde geçerli olan norm ve değer yargılarında uygun bir davranış geliştirme süreci; Aslantürk ve Amman'a, (2000) göre kişinin grup normlarına uyması ve bunları öğrenmesini sağlayan bir süreçtir. Fidan ve Erden'e (1986) göre ise sosyalleşme, hem birey hem de toplum açısından önemli bir süreçtir ve bu süreçte birey, ihtiyaçlarını toplumun beklentilerine uygun bir biçimde karşılamayı, toplumsal roller ile onları destekleyen tutumları, yaşamını sürdürmek için gerekli bilgi ve becerileri öğrenmektedir. Sosyalleşme sayesinde insan, toplumun ortaya koyduğu tavır ve hareket modellerini, örneklerini ve düşünme biçimlerini öğrenmektedir. Böylece sosyalleşme, kişinin toplumsal kültürle bütünleşmesini ve içinde yaşadığı topluma uyum sağlamasını mümkün kılmaktadır (Ozankaya, 1991).

Şahan (2007) ile Goffee ve Gareth (2003) göre sosyalleşme kriterleri aşağıdaki gibidir:

- Bireyin kendine güven duygusunun gelişmesi

- Bireyin kendini ifade edebilmesi

- Bireyde girişkenlik duygusunun gelişmesi

- Paylaşımci olma duygusunun oluşması

- Başarı ve başarısızlığı kabullenme

- Bireylerin yeteneklerinin ortaya çıkarılması

- Sosyal faydaya inanma

- Başkaları ile birlikte olmaktan haz duyma

- Sosyal gruplara katılma isteğinin artması

- Aidiyet duygusunun gelişmesi

- Başkalarının haklarına saygı gösterme

- Bencillikten uzaklaşma

- Centilmenlik

- Toplumsal kurallara uyma alışkanlığının gelişmesi

- Özgür düşünebilme ve karar verme yeteneğinin gelişmesi

-Takım çalışması

-Bilgi paylaşımı

-Yeni fikirlere açık olma

-Yaratıcı olma.

Bireylerin sosyalleşmesinde sosyal aktiviteler önemli birer yardımcılardır. Sosyal aktivite, keyifli bir ortamın yaratılmasıyla sonuçlanan bir iletişim biçimi olarak tanımlanmaktadır (Akgeyik, 2007). Bireylerin boş zamana yönelik ilgi ve isteklerinin iyi bilinmesi, onların boş zamanlarını olumlu bir şekilde değerlendirmelerini sağlamak için gereklidir. Aksi durumda, boş zamanlarının iyi değerlendirilmemesi ile bireylerin zararlı arkadaş gruplarına girmesi, zamanını kahvehanede geçirmesi, kumar, alkol, sigara ve uyuşturucu gibi kötü alışkanlıklar edinmesi sonucunda ruh sağlığının bozularak suça yönelmesi söz konusu olabilmektedir (Seçgin, 1996). Sosyal aktivitelerin rolü, özellikle günlük sorunlarla mücadele etmede ve kişisel ilişkilerde düşmanca tutum ve davranışların minimize edilmesinde oldukça büyüktür (Akgeyik, 2007). 
Öğretmen adayları, alan bilgisi ve pedagojik yeterliliklerin yanında, toplumun beklentilerini ve kendi ihtiyaçlarını karşılayabilecek yetiye sahip olmalıdır. $\mathrm{Bu}$ nedenle öğretmen adaylarının sosyal bir varlık olarak toplumun içinde yer alması gerekmektedir ve bu süreçte öğretmen adaylarının sosyal aktivite tercihleri önemli rol oynamaktadır. Fakat yapılan çalışmalar incelendiğinde öğretmen adaylarının sosyal aktivite tercihlerinin belirlenmesinde kullanılabilecek bir ölçeğin eksikliği dikkati çekmiştir. Pekince (2012) yürüttüğü tez çalışmasında ergenlerin sosyal aktivitelere katılım düzeylerini belirlemek amacıyla Sosyal İşlevsellik Ölçeği kullanmıştır.

Ölçek yapma işlemi olarak tanımlanan ölçeklemede kullanılan yaklaşımlar iki grupta toplanabilir. Bunlar; 1) Denek tepkilerine dayalı (cevaplayıcı merkezli) yaklaşımlar ve 2) Yargıcı kararlarına dayalı yaklaşımlardır (Kan, 2008). Denek tepkilerine dayalı yaklaşımlar ise uyarıcı değil, cevaplayıcı merkezlidir yani madde ya da uyarıcıların değil, cevapların ölçeklenmesi amacını güder (Torgerson, 1958; Tezbaşaran, 2004; aktaran, Arık ve Kutlu, 2013). Ceveaplayıcı merkezli (subject centered) yaklaşım, her bir cevaplayıcının maddelere verdiği tepkilere dayalı olarak bireyleri ölçek üzerinde farklı bir yere yerleştirmeye odaklanır (Crocker ve Algina, 1986). Cevaplayıcı merkezli yaklaşımlar da kendi içinde dört grupta toplanabilir. Bunlar; a) İkili karşılaştırmalar, b) Sınıflama yargıları, c) Mutlak yargilar, d)Siralama yargiları (Turgut ve Baykul, 1992). Yargicı kararlarına dayalı ölçekleme yaklaşımı, uyarıcıları uzman ya da bilirkişi yargılarına dayalı olarak belirli bir boyutta ölçeklemeyi içerir. Bu tür modeller gözlemcilerin her bir uyarıcının uyarıcılık derecesini belli bir yöntemle (sıralama, sınıflama, ikili karşılaştırma vb. gibi) belirlemelerine dayalıdır (Kan,2008). Yargıcı kararlarına dayalı ölçekleme yaklaşımlar da kendi içinde iki grupta toplanabilir. Bunlar; a)Dereceleme toplamları, b)Çok Boyutlu Ölçekleme (Turgut ve Baykul, 1992).

Ölçekleme, ölçme sürecinde nitel ayırımları gösteren gözlemlerden, nicel ayırımları gösteren ölçülere geçişte çok önemli bir halkayı içeren bir çalışma alanı olmasına rağmen Türkiye'de ve dünyada ölçekleme alanına dönük çalışmalar son derece kısıtlı olduğu görülmektedir (Albayrak ve Gelbal, 2012; Anıl ve Güler, 2006; Arık ve Kutlu, 2013; Bal, 2011; Bülbül ve Acar, 2012; Ekinci, Bindak ve Y1ldırım, 2012; Güler ve An1l, 2009; Kan, 2008; Kara ve Gelbal, 2013; Nartgün, 2006; Öğretmen, 2008; Ömür, 2009; Özer ve Acar, 2011; Öztürk, Özdemir ve Gelbal, 2011). Sosyal aktivite tercihleri ile ilgili alanyazın incelendiğinde ise sosyal aktivite tercihlerinin belirlenmesine dayalı doğrudan ölçekleme tekniklerinin kullanıldığı bir araştırmaya rastlanamamıştır.

Bireylerin sosyal aktivite tercihlerinde cinsiyet, kardeş sayısı, anne-babanın eğitim düzeyi, babanın mesleği etkili olmaktadır (Pekince, 2012). Fakat toplumda yer alan bireylerin önemli bir kısmını oluşturan öğretmen adaylarının sosyal aktivite tercihlerinin belirlenmesinde etkili olan faktörlerin belirlendiği çalışmaların olmayışı da ayrı bir eksikliktir. Bu amaçla bu çalışmada aşağıda verilen problemlere yanıt aranmıştır.

1. Öğretmen adaylarının sosyal aktivite tercihleri bulundukları üniversiteye göre uyum göstermekte midir?

2. Öğretmen adaylarının sosyal aktivite tercihleri puan türlerine göre uyum göstermekte midir?

3. Öğretmen adaylarının sosyal aktivite tercihleri cinsiyetlerine göre uyum göstermekte midir?

\section{Amaç ve Önem}

$\mathrm{Bu}$ çalışmada öncelikle öğretmen adaylarının sosyal aktivite tercihlerinin belirlenmesinde kullanılabilecek bir ölçme aracının geliştirilmesi daha sonra ise öğretmen adaylarının sosyal aktivite tercihlerinin, bulundukları üniversiteye, puan türüne (sayısal, eşit ağırlık, sözel ve 
yetenek) ve cinsiyete göre uyum gösterip göstermediğinin ikili karşılaştırmalı ölçekleme yöntemiyle belirlenmesi amaçlanmıştır. Uyarıcı sayısının fazla olmasından dolayı uyarıcıları öğretmen adaylarına ikişer ikişer sunulmasının öğretmen adaylarının tercih yapmasını kolaylaştıracağı düşünülmüş ve bu nedenle ikili karşılaştırmalı ölçekleme yöntemi tercih edilmiştir. Aynı zamanda bu çalışma öğretmen adaylarının en çok tercih ettikleri sosyal aktivitelerin belirlenmesi ve üniversitelerin bu tercihlere göre firsat sunmas1, daha az tercih edilen aktivitelerin daha çekici hale getirilmesi ve öğretmen adaylarının daha az tercih edilen bu aktivitelere yönlendirilmesi bakımından önemlidir. Çünkü öğretmen adaylarının daha nitelikli öğretmen olarak yetişebilmeleri, mesleki yeterliklerinin yanı sıra bireysel gelişimleri ile de ilişkilidir.

\section{YÖNTEM}

$\mathrm{Bu}$ çalışma ile daha önceden belirlenen sosyal aktivite çeşitlerinin öğretmen adaylarının verdikleri tepkilerine dayalı olarak ölçekleme tekniklerinden biri olan ikili karşılaştırmalarla ölçeklenmesi amaçlanmıştır. Bu açıdan yapılan çalışma betimsel bir araştırma niteliğindedir. Thurstone tarafından 1927 yılında bulunan ikili karşılaştırmalı ölçekleme yönteminin teorik temelini karşılaştırmalı yargılar kanunu oluşturur. İkili karşılaştırmalarla ölçekleme yönteminde uyarıcılar cevaplayıcılara ikişer ikişer sunulur ve cevaplayıcılardan iki uyarıcıdan birini seçmesi istenir (Turgut ve Baykul, 1992).

\section{Çalışma Grubu}

Çalışma, 2012-2013 eğitim öğretim yılında, Niğde Üniversitesi Eğitim Fakültesi Fen Bilgisi Eğitimi, Sınıf Öğretmenliği Eğitimi, Türkçe Eğitimi, Rehberlik ve Psikolojik Danışmanlık, Sosyal Bilgiler Eğitimi, Resim Eğitimi ve Müzik Eğitimi bölümlerinde öğrenim gören 174, Bülent Ecevit Üniversitesi Ereğli Eğitim Fakültesi Sınıf Öğretmenliği Eğitimi, Fen Bilgisi Eğitimi, İlköğretim Matematik Eğitimi ve Türkçe Eğitimi bölümlerinde öğrenim gören 201 öğretmen adayı olmak üzere toplam 375 öğretmen adayıyla yürütülmüştür. Çalışma grubuna ilişkin değişkenlerin frekans ve yüzde değerleri Tablo 1'de sunulmuştur.

Tablo 1. Çalışma Grubuna İlişkin Değişkenlerin Frekans ve Yüzde Değerleri

\begin{tabular}{llll}
\hline Değişken & & f & $\%$ \\
\hline Üniversite & Niğde Üniversitesi & 174 & 46,4 \\
& Bülent Ecevit Üniversitesi & 201 & 53,6 \\
\hline \multirow{2}{*}{ Puan türü } & Sayısal & 102 & 27,2 \\
& Eşit Ağırlık & 103 & 27,4 \\
& Sözel & 106 & 28,2 \\
& Yetenek & 64 & 17,2 \\
\hline Cinsiyet & Kadın & 252 & 67,2 \\
& Erkek & 123 & 32,8 \\
\hline
\end{tabular}

Çalışmaya katılan öğretmen adaylarının \%46,4'ü Niğde Üniversitesi’nde \%53, 6’s1 ise Bülent Ecevit Üniversitesi'nde ögrenim görmektedir. Öğretmen adaylarının \%27'si sayısal, \%27,4'ü eşit ağırlık, \%28,2'si sözel ve \%17,2'si yetenek puan türü ile üniversiteye girmişlerdir. Öğretmen adaylarının \%67,2'si kadın \%32,8'i ise erkektir.

\section{Veri Toplama Aracı}

Veri toplama aracının hazırlanmasında sosyal aktivitelerle ilgili alanyazın taraması yapılmış ve sosyal aktiviteler belirlenmiştir. Bir Psikolojik Danışmanlık ve Rehberlik ve bir Ölçme ve Değerlendirme uzmanından alınan görüşler doğrultusunda yedi sosyal aktiviteye karar 
verilmiştir. Daha sonra öğretmen adaylarının sosyal aktivite tercihlerini belirlemek amacıyla araştırmacılar tarafından sosyal aktivite tercihlerine ilişkin bir ölçme aracı hazırlanmıştır. Belirlenen sosyal aktiviteler ikili karşılaştırma yapılacak şekilde düzenlenmiştir. Öğretmen adaylarının samimi yanıtlar verip vermediğini belirlemek amacıyla sosyal aktivitelerin yerleri değiştirilerek üç kontrol maddesi konulmuş ve Sosyal Aktivite Tercih Envanteri uygulamaya hazır hale getirilmiştir.

\section{Verilerin Toplanmast}

Sayısal puan türüne ait veriler Niğde Üniversitesi Eğitim Fakültesi'nde Fen Bilgisi Öğretmenliği Bölümü'nde öğrenim gören öğretmen adayları ile Ereğli Eğitim Fakültesi Fen Bilgisi ve İlköğretim Matematik Öğretmenliği Bölümlerinde öğrenim gören öğretmen adaylarına uygulanarak, eşit ağırlık puan türüne ait veriler Niğde Üniversitesi Eğitim Fakültesi'nde Sınıf Öğretmenliği ve Psikolojik Danışmanlık Rehberlik Bölümü'nde öğrenim gören öğretmen adayları ile Bülent Ecevit Üniversitesi Ereğli Eğitim Fakültesi Sınıf Öğretmenliği Bölümünde öğrenim gören öğretmen adaylarına uygulanarak, sözel puan türüne ait veriler Niğde Üniversitesi Eğitim Fakültesi Türkçe Sosyal Bilgiler Öğretmenliği Bölümlerinde öğrenim gören öğretmen adayları ile Bülent Ecevit Üniversitesi Ereğli Eğitim Fakültesi Türkçe Öğretmenliği Bölümünde öğrenim gören öğretmen adaylarına uygulanarak, yetenek puan türüne ait veriler ise Niğde Üniversitesi Eğitim Fakültesi Resim ve Müzik Öğretmenliği Bölümlerinde öğrenim gören öğretmen adaylarına uygulanarak toplanmıştır.

Sosyal Aktivite Tercih Envanteri uygulandiktan sonra kontrol maddeleri ile tutarlılık göstermeyen 37 cevaplayıcının verileri analiz dışı bırakılmış ve veriler analize hazır hale getirilmiştir.

\section{Verilerin Analizi}

Öğretmen adaylarının sosyal aktivite tercihlerin belirlenmesinde ikili karşılaştırmalar ölçekleme yöntemi ile kullanılmış; hesaplamalar, V. hal denklemi ile tam veri matrisi üzerinden yapılmıştır. Sosyal Aktivite Tercih Envanteri ile toplanan veriler üzerinde belirlenen alt problemlere çözüm bulmak amacıyla aşağıdaki istatistiksel işlemler yürütülmüştür.

1. Bu çalışmada öncelikle her bir öğretmen adayından, ikili olarak sunulan sosyal aktivitelerden birini seçmeleri istenmiş ve her bir değişkenin alt grubuna ait frekans değerleri belirlenmiş ve bu işlem sonucunda da frekans matrisi (F) oluşturulmuştur.

Tablo 2. Niğde Üniversitesi Verilerine ait Frekans Matrisi

\begin{tabular}{llllllll}
\hline Uyarıcilar & Spor & Sinema & Tiyatro & Müze & Konser & Arkadaş & Konferans \\
\hline Spor & & 65 & 80 & 70 & 54 & 25 & 112 \\
\hline Sinema & 109 & & 126 & 109 & 63 & 41 & 130 \\
\hline Tiyatro & 94 & 48 & & 94 & 70 & 42 & 131 \\
\hline Müze & 104 & 65 & 80 & & 63 & 45 & 124 \\
\hline Konser & 120 & 111 & 104 & 111 & & 71 & 134 \\
\hline Arkadaş & 149 & 133 & 132 & 129 & 103 & & 22 \\
\hline Konferans & 62 & 44 & 43 & 50 & 40 & 152 & \\
\hline
\end{tabular}

2.Frekans (F) matrisinin her bir hücresindeki değer her bir değişkenin alt grubunda yer alan kişi sayısına $(\mathrm{N})$ bölünerek oranlar matrisi elde edilmiştir. 
Tablo 3. Niğde Üniversitesi Verilerine ait Oranlar Matrisi

\begin{tabular}{llllllll}
\hline Uyarıcılar & Spor & Sinema & Tiyatro & Müze & Konser & Arkadaş & Konferans \\
\hline Spor & 0,000 & 0,374 & 0,460 & 0,402 & 0,310 & 0,144 & 0,644 \\
\hline Sinema & 0,626 & 0,000 & 0,724 & 0,626 & 0,362 & 0,236 & 0,747 \\
\hline Tiyatro & 0,540 & 0,276 & 0,000 & 0,540 & 0,402 & 0,241 & 0,753 \\
\hline Müze & 0,598 & 0,374 & 0,460 & 0,000 & 0,362 & 0,259 & 0,713 \\
\hline Konser & 0,690 & 0,638 & 0,598 & 0,638 & 0,000 & 0,408 & 0,770 \\
\hline Arkadaş & 0,856 & 0,764 & 0,759 & 0,741 & 0,592 & 0,000 & 0,126 \\
\hline Konferans & 0,356 & 0,253 & 0,247 & 0,287 & 0,230 & 0,874 & 0,000 \\
\hline
\end{tabular}

3.Oranlar matrisindeki hücre değerlerine $(\mathrm{P})$ karşılık gelen $(\mathrm{Z})$ standart değerleri belirlenerek birim normal sapmalar matrisi elde edilmiştir. Matrisin sonunda her bir sütuna ait değerlerin toplamını gösteren bir satır oluşturulmuş ve bu satırdaki her bir z hücre değerinin sütunlar boyunca ortalamaları alınarak ölçek değerleri hesaplanmıştır.

Tablo 4. Niğde Üniversitesi Verilerine ait Birim Normal Sapmalar Matrisi

\begin{tabular}{llllllll}
\hline Uyarıcilar & Spor & Sinema & Tiyatro & Müze & Konser & Arkadaş & Konferans \\
\hline Spor & & $-0,322$ & $-0,101$ & $-0,247$ & $-0,495$ & $-1,064$ & 0,368 \\
\hline Sinema & 0,322 & & 0,595 & 0,322 & $-0,353$ & $-0,720$ & 0,665 \\
\hline Tiyatro & 0,101 & $-0,595$ & & 0,101 & $-0,247$ & $-0,702$ & 0,684 \\
\hline Müze & 0,247 & $-0,322$ & $-0,101$ & & $-0,353$ & $-0,648$ & 0,561 \\
\hline Konser & 0,495 & 0,353 & 0,247 & 0,353 & & $-0,233$ & 0,739 \\
\hline Arkadaş & 1,064 & 0,720 & 0,702 & 0,648 & 0,233 & & $-1,143$ \\
\hline Konferans & $-0,368$ & $-0,665$ & $-0,684$ & $-0,561$ & $-0,739$ & 1,143 & \\
\hline Toplam & 1,861 & $-0,832$ & 0,659 & 0,615 & $-1,955$ & $-2,223$ & 1,874 \\
\hline Ortalama & 0,266 & $-0,119$ & 0,094 & 0,088 & $-0,279$ & $-0,318$ & 0,268 \\
\hline
\end{tabular}

4.Eksenin başlangıcı (O noktası) bu satırdaki ortalama z değerlerinden en küçük olanına kaydırılarak ölçek değerleri (S) sıralanmıştır. Bu kaydırmada; eğer en küçük değer negatif ise tüm değerlere bu değerin mutlak değeri eklenir, en küçük değer pozitif olduğunda ise tüm değerlerden bu değer çıkarılır.

Tablo 5. Niğde Üniversitesi Verilerine ait Ölçek değerleri

\begin{tabular}{llllllll}
\hline \multicolumn{2}{c}{ Uyarıcilar } & & & & & & \\
& Spor & Sinema & Tiyatro & Müze & Konser & Arkadaş & Konferans \\
\hline $\mathrm{Sj}$ & 0,266 & $-0,119$ & 0,094 & 0,088 & $-0,279$ & $-0,318$ & 0,268 \\
& & & & & & & \\
\hline $\mathrm{Sj}$ & 0,584 & 0,199 & 0,412 & 0,406 & 0,039 & 0,000 & 0,586 \\
\hline
\end{tabular}

5.Her bir alt gruptaki öğretmen adaylarının sosyal aktivite tercihleri sıralamaları açısından nasıl bir ilişki olduğunu incelemek amacıyla Spearman Brown Sıra farkları korelasyon katsayısı kullanılmıştır. 


\section{BULGULAR VE YORUMLAR}

Çalışmanın bu bölümünde öğretmen adaylarının bulundukları üniversiteye, puan türlerine ve cinsiyetlerine göre ölçekleme işlemine ait bulgular sunularak elde edilen sonuçlar karşılaştırılmıştır.

Farklı üniversitelerde öğrenim gören ögretmen adaylarının sosyal aktivite tercihlerine ilişkin bulgular; Niğde Üniversitesi'nde ve Bülent Ecevit Üniversitesi'nde öğrenim gören öğretmen adaylarının sosyal aktivitelere ilişkin ölçek değerleri ve sıralamaları Tablo 2'de sunulmuştur.

Tablo 6. Öğretmen Adaylarının Bulundukları Üniversiteye Göre Sosyal Aktivite Tercihleri

\begin{tabular}{llccccccc}
\hline & & Spor & Sinema & Tiyatro & Müze & Konser & Arkadaş & Konferans \\
\hline Niğde & Ölçek değeri & 0,584 & 0,199 & 0,412 & 0,406 & 0,039 & 0,000 & 0,586 \\
Üniversitesi & Sı̈alama & 6 & 3 & 5 & 4 & 2 & 1 & 7 \\
\hline Bülent Ecevit & Ölçek değeri & 0,786 & 0,473 & 0,723 & 0,849 & 0,370 & 0,000 & 1,313 \\
Üniversitesi & Sıralama & 5 & 3 & 4 & 6 & 2 & 1 & 7 \\
\hline
\end{tabular}

Tablo 6'da verilen her bir sosyal aktivitenin ölçek değerleri ve sıralamaları incelendiğinde, her iki üniversitede öğrenim gören öğretmen adayları yedi sosyal aktivite arasından en çok sırasıyla arkadaşlarla beraber gezmeyi, konsere gitmeyi ve sinemaya gitmeyi tercih ettikleri en az ise konferans, seminer vb. toplantılara katılmayı tercih ettikleri görülmüştür. Spor yapma, tiyatroya gitme ve müze, sergi vb. gitme sosyal aktivitelerinin ölçek değerlerinin ise her iki üniversitede de birbirine çok yakın olduğu dolayısıyla da bu sosyal aktivitelerin çok fazla birbirinden ayırt edilemediği söylenebilir.

Ölçek puanları incelendiğinde, Bülent Ecevit Üniversitesi'nde öğrenim gören öğretmen adaylarının ölçek puanlarının Niğde Üniversitesi’nde öğrenim gören öğretmen adaylarının ölçek puanlarına göre daha fazla değişkenlik gösterdiği ve daha büyük olduğu tespit edilmiştir. Dolayısıyla Bülent Ecevit Üniversitesi'nde öğrenim gören öğretmen adaylarının Niğde Üniversitesi'nde öğrenim gören öğretmen adaylarına göre arkadaşlarla beraber gezmeyi diğer aktivitelere daha çok tercih ettikleri söylenebilir.

Tablo 7. Farklı Üniversitelerdeki Öğretmen Adaylarının Tercihleri Arasındaki Spearman Sira Farkları Korelasyon Katsayıları

\begin{tabular}{lrr}
\hline & Niğde & $\begin{array}{c}\text { Bülent } \\
\text { Ecevit }\end{array}$ \\
\hline Spearman's rho Niğde & 1,000 &, $893^{*}$ \\
\cline { 2 - 3 } & Bülent Ecevit & 1,000 \\
\hline *p<0,05
\end{tabular}

Tablo 7 incelendiğinde ikili karşılaştırmalı ölçekleme yöntemiyle elde edilen ölçek değerlerinin sıralamaları arasında pozitif yönlü, yüksek düzeyde ve anlamlı bir ilişkinin olduğu tespit edilmiştir $\left(\mathrm{r}_{\mathrm{s}}=0,893 ; \mathrm{p}<0,05\right)$. Bu bulgulara dayalı olarak her iki üniversitede öğrenim gören öğretmen adaylarının sosyal aktivite tercihleri arasında bir uyum olduğu ve bu durumun ise iki üniversitenin bulunduğu şehirlerin yapısı ile gelişmişlik düzeyinin birbirine yakın olmasından kaynaklandığı söylenebilir.

Farklı puan türüne sahip ögretmen adaylarının sosyal aktivite tercihlerine ilişkin bulgular; Niğde Üniversitesi’ne ve Bülent Ecevit Üniversitesi’ne sayısal, eşit ağırlık, sözel ve yetenek puanları ile giren öğretmen adaylarının sosyal aktivitelere ilişkin ölçek değerleri ve siralamaları Tablo 8'de sunulmuştur. 
Tablo 8. Ögrretmen Adaylarının Puan Türlerine Göre Sosyal Aktivite Tercihleri

\begin{tabular}{llccccccc}
\hline Puan türü & & Spor & Sinema & Tiyatro & Müze & Konser & Arkadaş & Konferans \\
\hline Sayısal & Ölçek değeri & 0,182 & 0,202 & 0,366 & 0,493 & 0,189 & 0,000 & 0,724 \\
& Siralama & 2 & 4 & 5 & 6 & 3 & 1 & 7 \\
\hline Eşit & Ölçek değeri & 0,973 & 0,604 & 0,913 & 1,172 & 0,411 & 0,000 & 1,554 \\
Ağırlık & Siralama & 5 & 3 & 4 & 6 & 2 & 1 & 7 \\
\hline Sözel & Ölçek değeri & 0,658 & 0,374 & 0,655 & 0,584 & 0,468 & 0,000 & 0,998 \\
& Siralama & 6 & 2 & 5 & 4 & 3 & 1 & 7 \\
\hline Yetenek & Ölçek değeri & 0,764 & 0,302 & 0,647 & 0,280 & 0,000 & 0,313 & 0,626 \\
& Siralama & 7 & 3 & 6 & 2 & 1 & 4 & 5 \\
\hline
\end{tabular}

Tablo 8 incelendiğinde, sayısal puanı ile üniversiteye giren öğretmen adaylarının en çok tercih ettikleri sosyal aktivitenin arkadaşlarıyla beraber gezmek olduğu, bu aktiviteyi ise sırasıyla spor yapma, konsere gitme ve sinemaya gitme sosyal aktivitelerinin takip ettiği ve bu üç aktiviteye ait ölçek puanlarının birbirine çok yakın olduğu görülmüştür. Dolayısıyla sayısal yetenek puanı ile üniversiteye giren öğretmen adaylarının bu üç sosyal aktiviteden birini tercih ederken birbirinden ayırt edemedikleri söylenebilir. $\mathrm{Bu}$ öğretmen adaylarının yedi sosyal aktiviteden en az tercihleri arasında ise sirasiyla müze ve sergiye gitme ile konferans, seminer vb. toplantılara katılma olduğu tespit edilmiştir.

Eşit ağırlık puanı ile üniversiteye giren öğretmen adaylarının en çok tercih ettikleri sosyal aktivitenin arkadaşlarıyla beraber gezmek olduğu, bu aktiviteyi ise sirasiyla konsere gitme, sinemaya gitme ve tiyatroya gitme sosyal aktivitelerinin takip ettiği görülmüştür. Bu öğretmen adaylarının yedi sosyal aktiviteden en az tercihleri arasında ise sırasıyla müze ve sergiye gitme ile konferans, seminer vb. toplantılara katılma olduğu tespit edilmiştir.

Sözel puanı ile üniversiteye giren öğretmen adaylarının da en çok tercih ettikleri sosyal aktivitenin arkadaşlarıyla beraber gezmek olduğu, bu aktiviteyi ise sırasıyla sinemaya gitme, konsere gitme ile müze ve sergiye gitme sosyal aktivitelerinin takip ettiği görülmüştür. Bu öğretmen adaylarının yedi sosyal aktiviteden en az tercihleri arasında ise sırasıyla spor yapma ve konferans, seminer vb. toplantılara katılma olduğu tespit edilmiştir.

Yetenek puanı ile üniversiteye giren öğretmen adaylarının da en çok tercih ettikleri sosyal aktivitenin ise diğer puan türlerinden farklı olarak konsere gitme, bu aktiviteyi de sırasıyla müze ve sergiye gitme ile sinemaya gitme sosyal aktivitelerinin takip ettiği belirlenmiştir. En az tercih edilen aktivitenin ise yine diğer puan türlerinden farklı olarak spor yapma olduğu, tiyatroya gitme sosyal aktivitesinin ise az tercih edilen diğer bir sosyal aktivite olduğu tespit edilmiştir.

Genel olarak ölçek puanları incelendiğinde sayısal, eşit ağırlık ve sözel puanlarıyla üniversiteye giren öğretmen adaylarının tercihleri arasında daha fazla benzerliklerin olduğu, her üç puan türünde de en fazla tercih edilen sosyal aktivitenin arkadaşlarla beraber gezme, en az tercih edilen sosyal aktivitenin ise konferans, seminer vb. toplantılara katılma olduğu tespit edilmiştir. Yetenek puanları ile üniversiteye giren öğretmen adaylarının ise en çok tercih ettikleri sosyal aktivitenin konsere gitme, en az tercih ettikleri sosyal aktivitenin ise spor yapma olduğu belirlenmiştir. 
Tablo 9. Farklı Puan Türü ile Üniversiteye Giren Öğretmen Adaylarının Tercihleri Arasındaki Spearman Sira Farkları Korelasyon Katsayıları

\begin{tabular}{llcccc} 
& & Sayısal & Eşit Ağırlık & Sözel & Yetenek \\
\hline Spearman'srho & Sayısal & 1,000 &, $786^{*}$ &, 571 &,- 071 \\
\cline { 2 - 6 } & Eşit ağıllık & & 1,000 &, $857^{*}$ &, 321 \\
\cline { 2 - 6 } & Sözel & & & 1,000 &, 571 \\
\cline { 2 - 6 } & Yetenek & & & & 1,000 \\
\hline
\end{tabular}

$* \mathrm{p}<0,05$

Tablo 9 incelendiğinde, sadece sayısal ve eşit ağırlık türü ile üniversiteye giren öğretmen adaylarının ikili karşılaştırmalı ölçekleme yöntemiyle elde edilen ölçek değerlerinin sıralamaları $\left(r_{s}=0,786 ; p<0,05\right)$ ile sözel ve eşit ağırlık türü ile üniversiteye giren öğretmen adaylarının ikili karşılaştırmalı ölçekleme yöntemiyle elde edilen ölçek değerlerinin sıralamaları arasında $\left(\mathrm{r}_{\mathrm{s}}=0,857 ; \mathrm{p}<0,05\right)$ arasında pozitif yönlü, yüksek düzeyde ve anlamlı bir ilişkinin olduğu belirlenmiştir. Bu bulgulara dayalı olarak sosyal aktivite tercihlerinde en fazla uyumun üniversiteye eşit ağırlık ile sözel puanları ile giren öğretmen adayları ve eşit ağırlık ile sayısal puanları ile üniversiteye giren öğretmen adayları arasında olduğu söylenebilir.

Yetenek puanı ile üniversiteye giren öğretmen adaylarının ölçek değerleri sıralamaları ile diğer puan türleriyle üniversiteye giren öğretmen adaylarının ölçek değerlerinin sıralamaları arasında istatistiksel olarak anlamlı bir uyuma rastlanmamıştır. $(\mathrm{p}<0,05)$. Bu sonuca dayalı olarak yetenek puanları ile üniversiteye giren öğretmen adaylarının sosyal aktivite tercihlerinin diğer puan türleri özellikle de sayısal puan türü ile üniversiteye giren öğretmen adayları ile farklılık gösterdiği söylenebilir. Dolayısıyla bu bulgulara dayanarak puan türünün öğretmen adaylarının sosyal aktivite tercihlerinde önemli bir etken olduğu söylenebilir.

Kadın ve erkek ögretmen adaylarının sosyal aktivite tercihlerine ilişkin bulgular; Niğde Üniversitesi'nde ve Bülent Ecevit Üniversitesi'nde öğrenim gören öğretmen adaylarının cinsiyetlerine göre sosyal aktivitelere ilişkin ölçek değerleri ve sıralamaları Tablo 10'da sunulmuştur.

Tablo 10. Öğretmen Adaylarının Cinsiyetlerine Göre Sosyal Aktivite Tercihleri

\begin{tabular}{llccccccc}
\hline Cinsiyet & & Spor & Sinema & Tiyatro & Müze & Konser & Arkadaş & Konferans \\
\hline Kadın & Ölçek değeri & 1,149 & 0,270 & 0,626 & 0,712 & 0,362 & 0,000 & 1,102 \\
& Sıralama & 6 & 2 & 4 & 5 & 3 & 1 & 7 \\
\hline \multirow{2}{*}{ Erkek } & Ölçek değeri & 0,463 & 0,737 & 0,994 & 0,995 & 0,644 & 0,000 & 1,495 \\
& Sıralama & 2 & 4 & 6 & 5 & 3 & 1 & 7 \\
\hline
\end{tabular}

Tablo 10 incelendiğinde, kadın öğretmen adaylarının en çok tercih ettikleri sosyal aktivitenin arkadaşlarıyla beraber gezme olduğu, bu sosyal aktiviteyi sırasıyla sinemaya gitme, konsere gitme ve tiyatroya gitme aktivitelerinin takip ettiği belirlenmiştir. Kadın öğretmen adaylarının yedi sosyal aktiviteden en az tercih ettikleri sosyal aktiviteler ise sırasıyla konferans, seminer vb. toplantılara katılma ve spor yapma olduğu tespit edilmiştir.

Erkek öğretmen adaylarının en çok tercih ettikleri sosyal aktivitenin de arkadaşlarıyla beraber gezme olduğu, bu aktiviteyi sırasıyla spor yapma, konsere gitme ve sinemaya gitme sosyal aktivitelerinin takip ettiği görülmüsstür. Erkek öğretmen adaylarının 
yedi sosyal aktiviteden en az tercih ettikleri ise sırasıyla konferans, seminer vb. toplantılara katılma ve tiyatroya gitme olduğu tespit edilmiştir.

Kadın ve erkek öğretmen adaylarının sosyal aktivite tercihleri incelendiğinde en çok tercih ettikleri ve en az tercih ettikleri sosyal aktiviteler arasında uyum olduğu belirlenmiştir. Fakat erkek öğretmen adayları spor yapmayı diğer aktivitelere göre daha çok tercih ederken, kadınların bu aktiviteyi çok fazla tercih etmedikleri belirlenmiştir.

Tablo 11. Kadın ve Erkek Öğretmen Adaylarının Tercihleri Arasındaki Spearman Sira Farkları Korelasyon Katsayıları

\begin{tabular}{llrr}
\hline & & Kadın & Erkek \\
\hline \multirow{2}{*}{ Spearman'srho } & Kadın & 1,000 &, 429 \\
\cline { 2 - 4 } & Erkek & & 1,000 \\
\hline
\end{tabular}

Tablo 11 incelendiğinde ikili karşılaştırmalı ölçekleme yöntemiyle elde edilen ölçek değerlerinin sıralamaları arasında pozitif yönlü, orta düzeyde fakat istatistiksel olarak anlamlı olmayan bir ilişkinin olduğu tespit edilmiştir $\left(r_{s}=0,429 ; p>0,05\right)$. Bu bulguya dayalı olarak kadın ve erkek öğretmen adaylarının sosyal aktivite tercihleri arasında uyum olmadığı, cinsiyetin sosyal aktivite tercihlerinde önemli bir etken olduğu söylenebilir.

\section{SONUÇLAR VE ÖNERİLER}

Sosyal Aktivite Tercih Envanteri'nin öğretmen adaylarına uygulanması sonucunda, her iki üniversitede öğrenim gören öğretmen adaylarının sosyal aktivite tercihlerinin birbiriyle uyumlu olduğu sonucuna ulaşılmıştır. Farklı puan türü ile üniversiteye giren öğretmen adaylarının sosyal aktivite tercihlerinin farklılık gösterdiği, bu farklılığın özellikle yetenek puan türü ile diğer puan türleri ile üniversiteye giren öğretmen adaylarının sosyal aktivite tercihleri arasında olduğu tespit edilmiştir. Ayrıca kadın ve erkek öğretmen adaylarının sosyal aktivite tercihlerinin birbiriyle uyumlu olmadığ 1 belirlenmiştir. Sosyal aktivite tercihinde cinsiyetin önemli bir etken olduğu Pekince(2012) tarafindan elde edilen bulgular ile benzerlik göstermektedir.

$\mathrm{Bu}$ sonuçlara dayanarak, araştırmacılara bu yedi aktiviteyi ikili karşılaştırma yöntemiyle ölçekleme ile birlikte sıralama yargılarıyla ölçekleme ile öğretmen adaylarına sunarak sonuçları karşılaştırmaları önerilebilir. Ayrıca araştırmacılara, bu çalışmayı farklı yaş grupları ile veya eğitim fakültesi dışındaki öğrencilerle de tekrarlayarak sosyal aktivite tercihleri arasındaki uyuma bakmaları önerilebilir. Araştırma sonuçlarına dayanarak öğretmen yetiştiren kurumlara, öğretmen adaylarının tercihlerini gözönüne alarak öğretmen adaylarına firsatlar sunmaları ve tercih edilmeyen aktiviteleri cazip hale getirmeleri önerilebilir.

\section{KAYNAKLAR}

Akgeyik, T. (2007). Pozitif kurumsal kültürü geliştirmede işyerinde sosyal aktivite uygulamalari. İktisat Fakültesi Mecmuast. 56 (2). 55-94.

Albayrak, A. ve Gelbal, S. (2012). İkili karşılaştırmalar yargılarına ve sıralama yargılarına dayalı ölçekleme yaklaşımlarından elde edilen ölçek değerlerinin tutarlığının karşılaş̧ırılması. 21. Ulusal Eğitim Bilimleri Kongresi, 12-14 Eylül 2012. İstanbul.

Anıl, D. ve Güler, N. (2006). İkili karşılaştırma yöntemi ile ölçekleme çalışmasına bir örnek. Hacettepe Üniversitesi Eğitim Fakültesi Dergisi, 30, 30-36.

Arık, R. S. ve Kutlu, Ö. (2013). Öğretmenlerin ölçme ve değerlendirme alanı yeterliklerinin yargıcı kararlarına dayalı ölçeklenmesi [Scaling primary school teachers' competence based on judgmental decisions in the field of measurement and evaluation]. Eğitim Bilimleri Araştırmaları Dergisi - Journal of Educational Sciences Research, 3 (2), 163-196.

Aslantürk, Z. ve Amman, T. (2000). Sosyoloji. İstanbul: Kaknüs Yayınları. 
Bal, Ö. (2011). Seviye belirleme sınavı (sbs) başarısında etkili olduğu düşünülen faktörlerin sıralama yargıları kanunuyla ölçeklenmesi. Ĕ̆itimde ve Psikolojide Ölçme ve Değerlendirme Dergisi, 2 (2), 200-209.

Binbaşığlu, C. (1982). Ĕ̆itim psikolojisi, Ankara: Binbaşığlu Yayınevi

Bülbül, T. and Acar, M. (2012). A pair-wise scaling study on the missions of education supervisors in turkey. International Journal of Human Sciences, 9 (2), 623-640.

Crocker, L. and Algina, J. (1986). Introduction to classical and modern test theory. Florida: Holt, Rinehart and Winston Inc.

Ekinci, A., Bindak , R. ve Yıldırım, C. (2012). İlköğretim okulu yöneticilerinin öğretmenlerin mesleki sorunlarına empatik yaklaşımlarının ikili karşılaştırmalar metodu ile incelenmesi. Gaziantep Üniversitesi Sosyal Bilimler Dergisi, 11 (3), 759-776.

Fidan, N. Ve Erden M. (1986). Eğitim bilimine giriş. Ankara: Hacettepe Üniversitesi Eğitim Fakültesi Yayınları.

Goffee, R. And Gareth, J (2003) Kurum Kültürü. (Çev.: K. Kutmandu). İstanbul: Medicat Kitaplar1.

Güler, N. and Anıl, D. (2009). Scaling through pair-wise comparison method in required characteristics of students applying for post graduate programs. International Journal of Human Sciences, 6 (1), 627-639.

Kağıtçıbaşı, Ç.(2010). Günümüzde insan ve insanlar: Sosyal psikolojiye giriş. İstanbul: Evrim Yayınları

Kan, A. (2008). Yargıcı kararlarına dayalı ölçekleme yöntemlerinin karşılaştırılması üzerine ampirik bir çalışma. Hacettepe Üniversitesi Ĕ̈itim Fakültesi Dergisi, 35, 186-194.

Kara, Y.ve Gelbal, S. (2013). İlköğretim Öğrencilerinin Başarılarını Etkileyen Özelliklerin Tam Sıralama Halinde İkili Karşılaştırmalar Yöntemiyle Ölçeklenmesi. Eğitimde ve Psikolojide Ölçme ve Değerlendirme Dergisi, 4(1), 33-51

Nartgün, Z, (2006). Öğretmenlik meslek bilgisi derslerinin önem düzeyinin ikili karşılaştırmalarla ölçeklenmesi, A.İ.B. Ü. Eğitim Fakültesi Dergisi, 6 (2), 161- 176.

Ozankaya, Ö. (1991). Toplumbilim. İstanbul: Cem Yayınevi.

Öğretmen, T. (2008). Alan tercih envanteri: ölçeklenmesi, geçerliği ve güvenirliği. Türk Ĕ̆itim Bilimleri Dergisi, 6 (3), 507-522.

Ömür, S. (2009). Dereceli puanlama anahtarıla, genel izlenimle ve ikili karşılaştırmalar yöntemiyle yapılan değerlendirmelerin karşılaştırılması. Yayımlanmamış Yüksek Lisans Tezi. Mersin Üniversitesi Sosyal Bilimler Enstitüsü, Mersin.

Özer, Y. \& Acar, M. (2011). Öğretmenlik mesleği genel yeterlikleri üzerine ikili karşılaştırma yöntemiyle bir ölçekleme çalışması. Çukurova Üniversitesi Ë̆itim Fakültesi Dergisi, 3 (40), 89-101.

Öztürk, N., Özdemir, S. \& Gelbal, S. (2011). İki farklı ölçekleme yaklaşımından elde edilen ölçek değerleri tutarlılığının incelenmesi. 20. Ulusal Eğitim Bilimleri Kurultayı, 8-10 Eylül 2011. Burdur.

Pekince, H. (2012). Ergenlerin saldırganlık düzeyleri ile sosyal aktivitelere katılımları arasındaki ilişkinin incelenmesi. Yükseklisans Tezi, İnönü Üniversitesi, Sağlık Bilimleri Enstitüsü, Malatya.

Seçgin, H. (1996). Ortaöğretim kurumlarinda eğitsel kol çalışmalarının boş zaman değerlendirmesine katkıları: İzmir örneği. Doktora Tezi. Dokuz Eylül Üniversitesi Sosyal Bilimler Enstitüsü, İzmir.

Şahan, H.( 2007). Üniversite ögrrencilerinin sosyalleşme sürecinde spor aktivitelerinin rolü. Doktora Tezi, Selçuk Üniversitesi, Sosyal Bilimler Enstitüsü, Konya.

Turgut M.F. ve Baykul, Y. (1992). Ölçekleme teknikleri. Ankara: ÖSYM Yayınları.

\section{Introduction}

\section{Extended Abstract}

Human is not only biological but also a social creature. So, in order to realize themselves, humans should meet their social needs as well as their physiological needs beginning from their birth because socialization, belonging to a group is one of basic needs of humans. Socialization is a lifelong learning process. Socialization is a significant process for both the individual and also the society. In this process, the individual learns to meet the expectations of the society appropriately, social roles and their supporting attitudes, and necessary information and skills to survive.

Social activities are important proponents for individuals' socialization. To know the individuals' interests and wishes towards free time well is necessary for them to help them spend their time effectively. On the contrary, the individuals can get into harmful friend groups, or get bad habits like gambling, alcohol, smoking or drugs, resulting in their psychological disorders and leading them to crime. The role of social activities is relatively 
significant especially to dealing with daily problems and minimizing the hostile attitudes and behaviours in personal relationships.

Candidate teachers should have the ability to meet the needs of society and their own needs as well as their field knowledge and pedagogical skills. So, candidate teachers should take place in the society as a social creature and their preferences of social activities have a significant role in this process. However, after the investigation of the research, it is noticed that there is a deficiency of a scale that can be used to determine the social activity preferences of candidate teachers.

Gender, number of siblings, education level of parents and the father's job are effective in the social activity preference of the individuals. It is also an important deficiency that there is no research which determines the factors for preferences of social activity of candidate teachers, who build up the individuals constituting an important part of the society. For this purpose, whether the candidate teachers' social activity preferences fit their universities, their type of scores in University Entrance Exam and their genders is investigated.

\section{Method}

As the types of activities determined with this study are aimed to be scaled with pair wise comparison based on the candidate teachers' reactions, this is a descriptive research. The study has been conducted to 375 candidate teachers, 174 of them being candidate teachers from the Science, Primary School, Turkish, Social Sciences, Art, Music Teachings and Psychological Counseling and Guidance departments of Niğde University Faculty of Education and 201 of them being candidate teachers from the Science, Elementary Mathematics and Turkish Teachings departments of Bülent Ecevit University in the 20122013 educational year.

The Social Activity Preference Scale has been organized in such a way that it allows pair wise comparison of the seven social activities which have been determined in accordance with literature review and expert opinion. In order to determine whether the candidate teachers give true answers or not, three control items are also put by changing the places of the social activities.

In determining of candidate teachers' social activity preferences, V. Situation equation of pair wise scaling method was used. In this process, firstly the candidate teachers are asked to prefer one of the activities presented dichotomously. Then, variable related frequency values are counted and frequency matrix is counted. Rates matrix is obtained by dividing the value in each cell of matrix to the number of people in sub-group of each variable. By determining standard values holding for cell values in rates matrix, normal deviations matrix is obtained. A line showing the sum of the values of each column is created at the end of the matrix and every $\mathrm{z}$ cell value in this line is averaged along the columns and the scale values are amounted in this way. Scale values are ordered by sliding the beginning of the axis to the smallest $\mathrm{z}$ value in this line. In this sliding, if the smallest value is negative, its absolute value is added to all values and if it is positive, its absolute value is subtracted from all the values. In order to investigate the relationship between social activity preferences of candidate teachers in each subgroup according to their order, Spearman Brown order differences correlation coefficient was used.

\section{Results and Discussion}

According to the results, candidate teachers who are cand of both universities most preferred activity is hanging out with friends and least activity is participating in conferences, seminars or meetings. When Spearman Brown correlation coefficient analyzed, 
it can be concluded that there is a harmony between the activity preferences of candidate teachers.

According to the results, the most preferred activities by the candidate teachers who entered the university with numerical score, equally-weighted score and verbal score is hanging out with friends, and the least preferred activity by them is participating in conferences or seminars. The most preferred activity by the candidate teachers who entered the university with aptitude score being different from the other type of scores is going to concerts and the least preferred activity by them being different from the other types scores is doing sports. When the correlation coefficients analyzed, it can be clearly concluded that the most harmony in the activity preferences is between the candidates who entered the university with equally-weighted and verbal scores, and equally-weighted and numerical scores. It is also concluded that the social activity preferences of the candidates who enter the university with aptitude test are different from the other score types, especially the numerical score.

It was determined that both female and male candidate teachers the most preferred social activity is hanging out with friends and the least preferred activity is conferences, seminars and so on. Analyzing correlation coefficients of male and female teachers is not harmony between social activity preferences, but also for gender can be said to be an important factor in their social activity choice.

Recommendations for the researchers are comparing scaling with pair wise comparison and Rank-Order Judgments Scaling method for these seven activities, repeating this methods for different age scales and different faculties. For universities; taking into account the preferences of candidate teachers' provide opportunities for candidate teachers' to glamorize proposed non-preferred activities. 